\title{
An Indepth Understanding of e-Governance initiatives: e-Procurement- A Great Success in Odisha
}

\author{
Shaikh Imtiyaj ${ }^{1}$, Er. Govinda Chandra Mangual ${ }^{2}$ \\ ${ }^{I}$ Senior Programmer, eProcurement Project, Ministry of Elect \& IT, NIC, Bhubaneswar, Odisha, India \\ ${ }^{2}$ Chief Engineer cum Chief Manager (Tech),eProcurement Cell, Govt. of Odisha, Bhubaneswar, Odisha, India
}

\section{Introduction}

Odisha is the first position among smart cities. The capital of Odisha, Bhubaneswar is the Number.1 smart city in the country. e-Governance aims to provide good governance to the public by using the Information and Communication Technology (ICT) for speedy, accurate, transparent and secured services. Information and Communication Technology is being increasingly used in daily life of a common man and it has become the nucleus part of providing the better governance services to the citizens of a country. Now a days, departments, business sectors and customers alike collect, store and transmit vast amount of information electronically and they want to believe that this information is secure. Hash functions are the most widespread among all cryptographic primitives and are currently used in multiple cryptographic schemes and security protocols. A Digital Signature Certificates (DSC) provides high level of security for online transactions. We study from various Government of Odisha departments like Works, water Resources, RD, H \& UD, SC \& ST Development, Agriculture Dept etc and state PSUs like IDCO, OFDC, OMC etc. Central Government departments like Dept. of Posts, CRPF and Central Government PSUs like NALCO, Paradip Port Trust etc. This study focuses a humble effort towards nobel goal of developing the easy and secure way of tendering process among departments and bidders of Odisha in public domain. The basic objective of research is to provide a model for better implementation of e-Governance application.

The use of Information Technology particularly web based internet applications to enhance the access to and delivery of government information and services to their citizens, public agencies, employees, business partners, financial institutions and government departments. The rapid growth of competition in the market and the consequent changes in economic conditions impose organizations and firms to implement new technologies to stay competitive. The Central, State Government, Judiciary, Autonomous Bodies, Boards \& Corporations, PSUs, Joint Ventures, Statutory Bodies, Commissions and Councils have invested in numerous initiatives throughout the length and breadth of the country aimed at extending the benefits of information revolution to rural and remote area. The Government envisions providing good governance by establishing a Committed, Accountable, Responsive, Inspiring, Nationalist, and Genuine Government - CARING Government. eProcurement is one of the best vehicles that are being gainfully used in reaching the goal of CARING governance.

The rapidly changing pace of the global business world compels organizations to take quick, decisive action when considering new technological developments. The technological developments and movement toward a global marketplace over the past decade have forced companies to restructure their business practices in order to gain competitive advantage or even to survive. One aspect of the restructuring has been the transition of several business processes into the electronic environment of cyberspace, commonly referred to as eBusiness. While e-Business includes all aspects of doing business in an electronic environment, two specific areas deal primarily with external transactions, specifically the e-Commerce and e-Procurement processes. The benefits include decreased administration and overhead costs, decreased labor hour cost per transaction, more accurate and timely business intelligence, more timely payment, and enhanced cash flow management. However the most striking benefit will be to get organizations to analyze their procurement processes.

\footnotetext{
e-Governance: Objective

- Providing information speedily to all citizens

- Improving transparency

- Improving public services such as transportation, power, health, water, security and municipal services etc.

$\checkmark$ Reduce Corruption
}

e-Governance development models :

The e-Governance Models are

- G2C : Government to Citizens

- G2B : Government to Business

G2G : Government to Government 


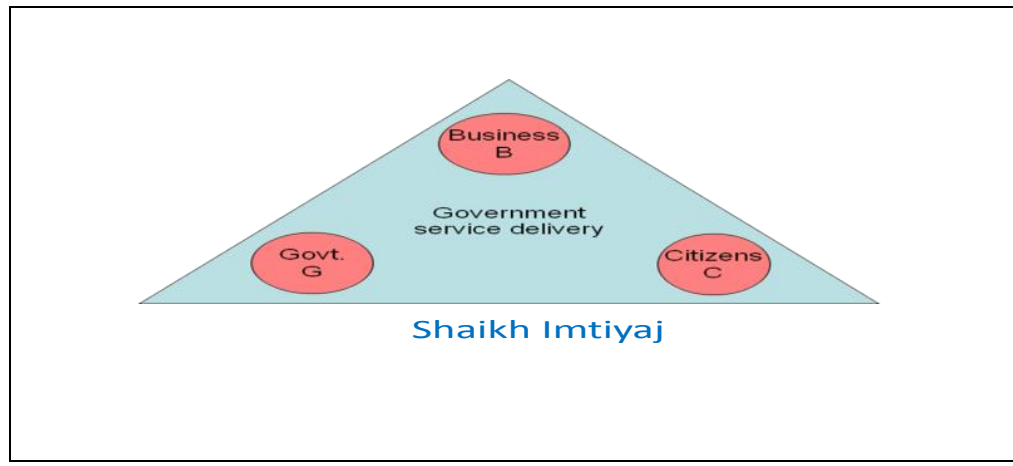

Figure 1: Governance Development Model

\section{e-Procurement:}

A major Government to Business e-Governance initiative to bring transparency in public procurement process is e-Procurement.

e-Procurement, commonly known as Electronic procurement.

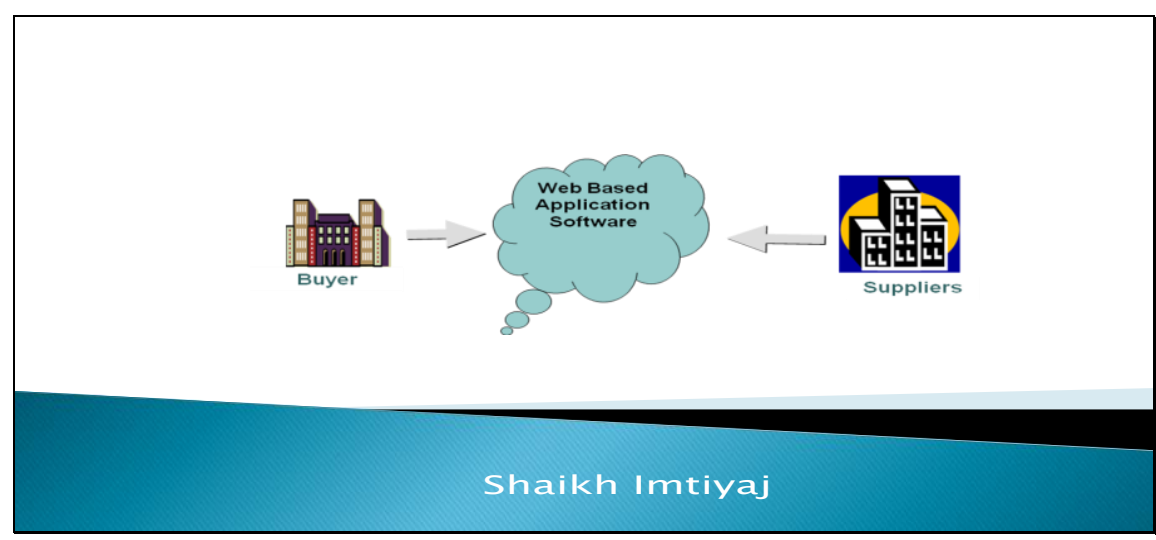

Figure 2: e-Procurement Cycle

e-Procurement is the business-to-business or business-to-consumer or business-to-Government purchase and sale of Supplies, Works and Services using the Internet. e-Procurement caters to the online tendering process from online tender creation to award of contract(AOC). Using e-Tendering the Departments can create the tender, publish the tender, receive bids, open the tenders, evaluate tenders and finally publish award of contract. Using e-Tendering, the bidders can search tenders, submit bids online and track the status of their bids. Timely and efficient delivery of e-Governance services is an important aspect. Indian IT-Act 2000 has mandated the usage of Digital Signature Certificate (DSC) for e-Procurement.

\section{e-Tendering Process :}

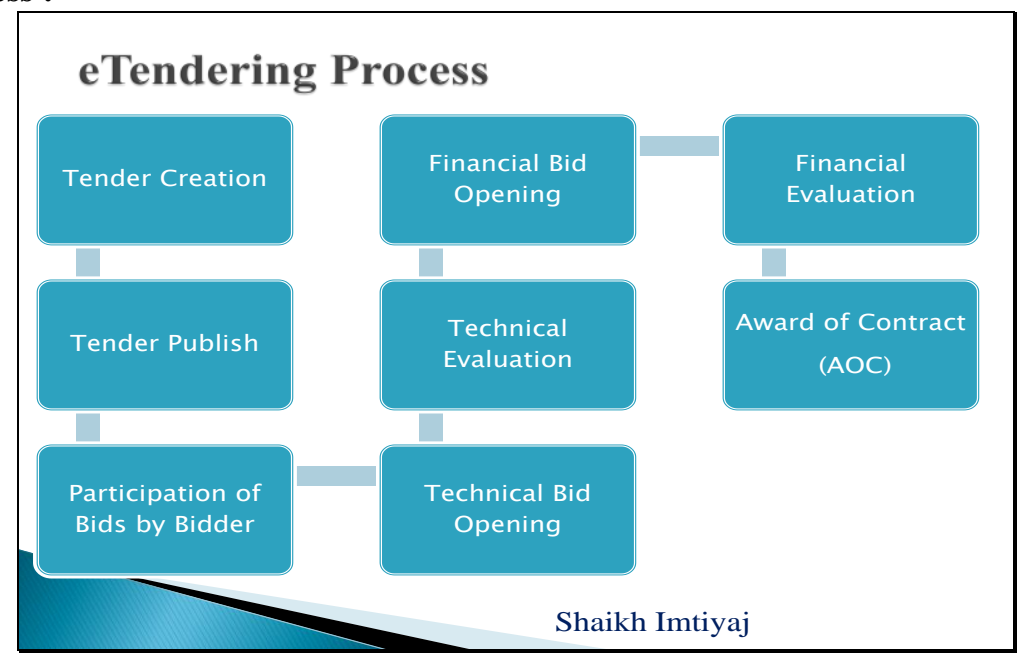

Figure 3: e-Tendering Process 


\section{Benefits of e-Procurement:}

For data encryption and security purposes, the Digital Signature Certificate is essential to operate in eProcurement.

\section{Benefits of e-Procurement}

- Healthy competition in participation

- Bidding possible: 24X7 Availability

- Any time, Any where Bid Submission

- Paper less Environment

- Process Efficiency in entire tendering process

- Real time monitoring

- Cost Reduction

- Reduced Tender related Crime

- Transparency

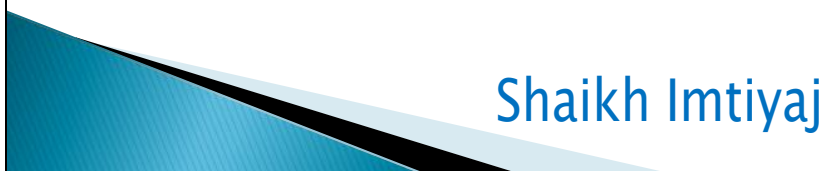

Figure 4: Benefits of e-Procurement

\section{Roles in e-Procurement:}

- Creater of the Tender: - The Tender will be created by the officer by using his/her Digital Signature Certificate, as per approved by the Department Nodal Officer.

- Publisher of the Tender:- He will be normally the Head of the Dept (HOD) of the concerned technical department and will be the responsible person for timely and accurately hosting of tender on the portal

- Opener of the Tender: - The tender will be decrypted and opened with the Digital Signature Certificates of each opener as identified during publishing the tender. Each opener will have to access one by one for bid opening. The Tender technical core committee members will be normally the openers of tender as decided by the Nodal Officer.

- Evaluator of the Tender: - The Evaluator is the person who will evaluate the tenders and upload the final decision of the Tender Evaluation Committee.

- Auditor: He will be given privileged access to audit tendering process.

\section{Risk in e-Procurement:}

Digital Signature Certificates (DSC) can be presented electronically to prove the identity, to access information or services on the Internet or to sign certain documents digitally. DSC provides Authorization, Authentication, Privacy, Non repudiation and Integrity. IT Act 2000 in Government of India gives legal validity to electronic transactions that are digitally signed. A DSC provides high level of security for online transactions. You can use certificates to encrypt information such that only the intended recipient can read it. You can digitally sign information to provide assurance to the recipient that it has not been altered in transit, and enable verification that you actually sent the message. 


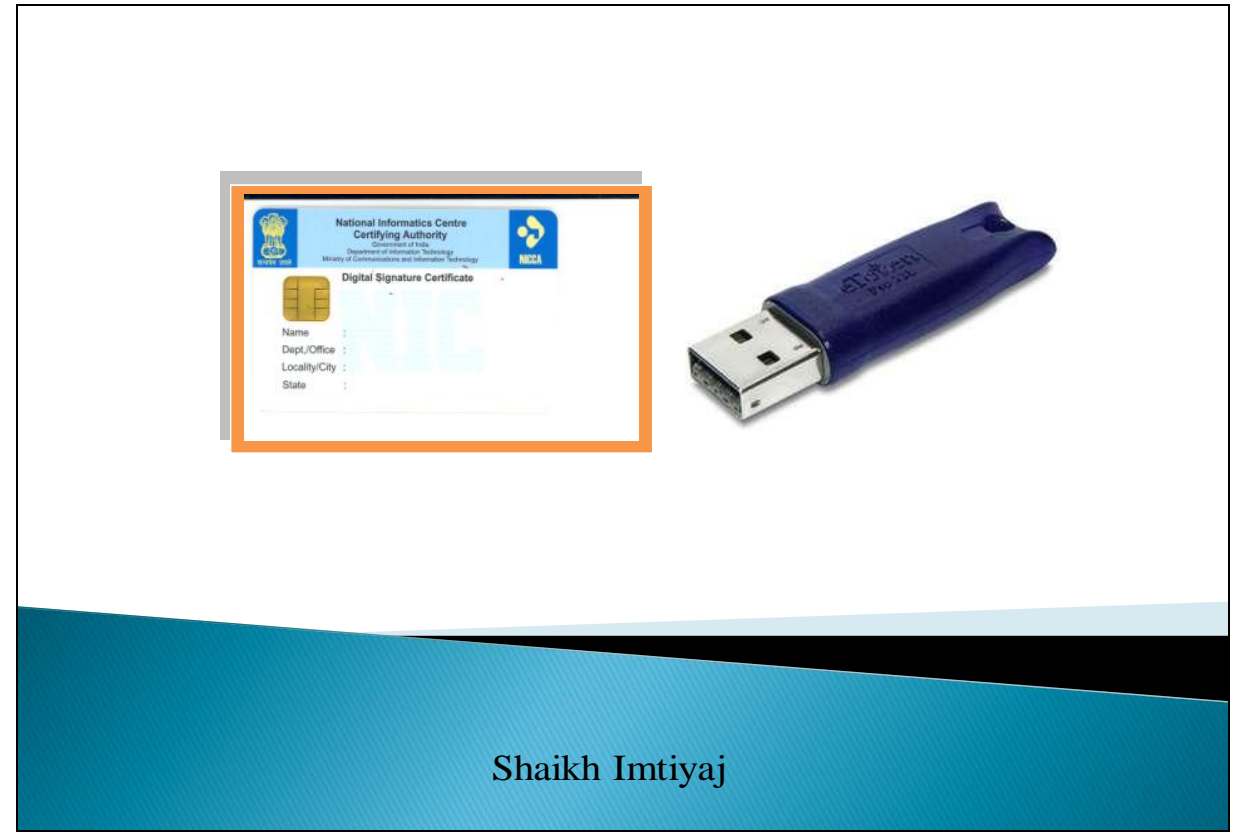

Figure 5: Digital Signature Certificates-Smart Card / eToken

Bidder module:

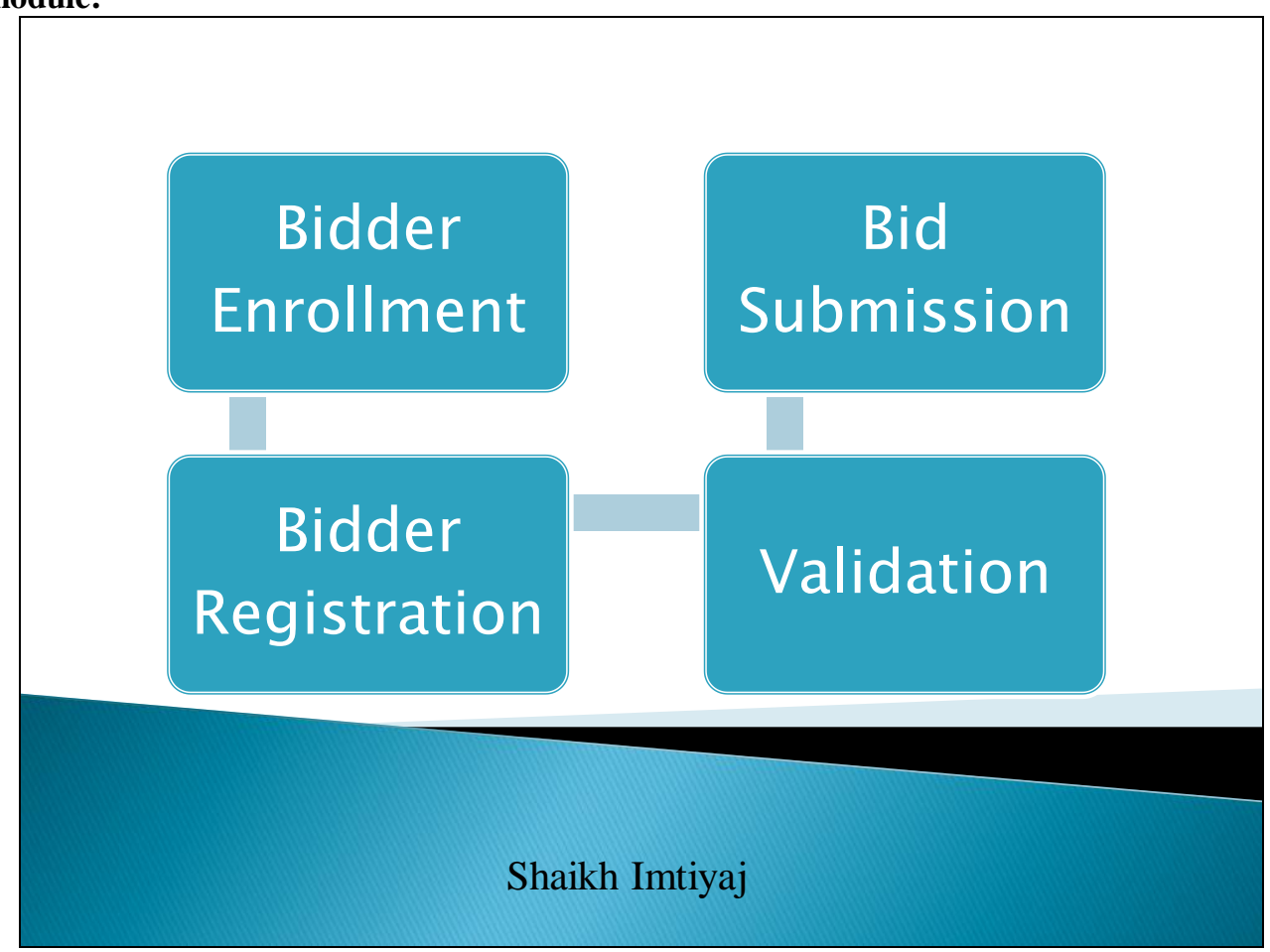

Figure 5: Bidder Process

- Bidder Enrollment: - Bidder submits valid login ID and follows the password policy to provide password. Bidder provides detail information to the portal.

- Bidder Registration: - Here bidder signing certificate is to be register in the Government of odisha eProcurement portal.

- Validation: - According to Government of Odisha protocols, the bidder's original documents will check and if comply then provides Validation. The years of validation are 1year or 3 years as concern departments rules and regulation. 
- Bid Submission:-

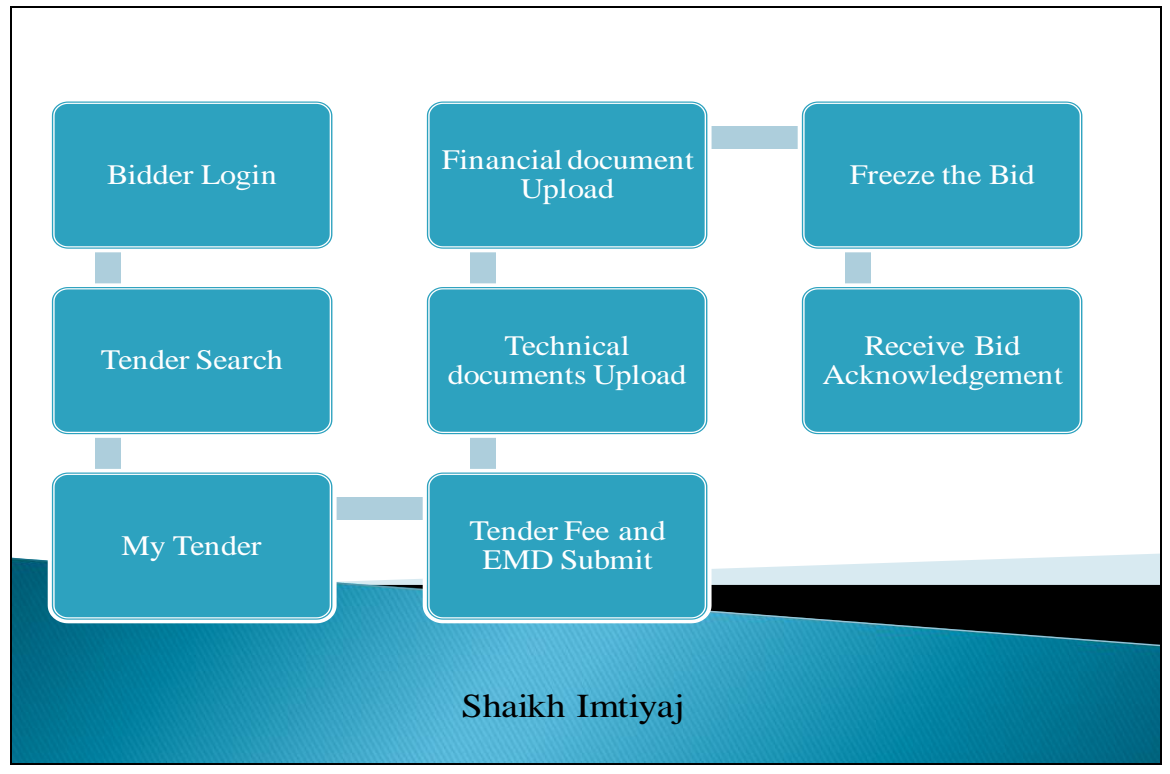

\section{Algorithm:}

DSC is based on MD5 algorithm from Cryptography. MD5 is Message Digest algorithm, which takes as input a message of arbitrary length and produces as output a 128-bit "message digest" of the input. MD5 is more secure than MD4.

\section{Implementation:}

Government of Odisha departments:-

Works, water Resources, RD, H \& UD, SC \& ST Development, Agriculture Dept etc

State PSUs:-

IDCO, OFDC, OMC etc.

Central Government departments: -

Dept. of Posts, CRPF etc

Central Government PSUs: -

NALCO, Paradip Port Trust etc

\section{Conclusion and Future Work}

The implementation of online tendering system is increasing day by day among different departments and PSUs for its secure, transparency and time stamping technique. e-Procurement provides the healthy competition among bidders which reduces the tender related crimes is certainly a significant achievement on the way to a better, cleaner, honest and developed nation. This study focuses on different opportunities of G2B initiatives in India. The basic objective of research is to provide a model for better implementation of eGovernance application.

\section{References}

[1]. Shaikh Imtiyaj, N.R Biswal, T.P Ray, Dr A.K Hota , "An Indepth Understanding of e-Procurement: A Case Study Approach", IOSR Journal of Computer Engineering (IOSR-JCE) e-ISSN: 2278-0661,p-ISSN: 2278-8727, Volume 17, Issue 6, Ver. V (Nov Dec. 2015), PP 20-24 www.iosrjournals.org

[2]. Shaikh Imtiyaj, N.R Biswal, T.P Ray, Dr A.K Hota , "Digital Signature Certificate: A blessing for e-Governance Application in Human Development", International Journal of Advanced Research in Science, Engineering and Technology,Vol. 2, Issue 1, pp 350-355,January 2015

[3]. William S.," Cryptography and Network Security, Principles and Practice", Prentice Hall of India, 2005.

[4]. Dhiren R. Patel ,'Information Security Theory and Practice", 2008 Edition

[5]. Atul Kahate, "Cryptography and Network Security", Second Edition

[6]. Cryptography Engineering: Design Principles and Practical Applications by Niels Ferguson, Bruce Schneier, Tadayoshi Kohno

[7]. www.eprocure.gov.in/eprocure/app, last visited $08^{\text {th }}$ Aug 2016

[8]. https://tendersodisha.gov.in/nicgep/app, last visited 08th Aug 2016

[9]. "Digital Signature," available at: http:// http://nicca.nic.in , last visited 08th Aug 2016

[10]. "e-Governance," available at http:// india.gov.in, last visited 08th Aug 2016

[11]. "e-Procurement," available at http:// demoeproc.nic.in, last visited 08th Aug 2016

[12]. smartcitybhubaneswar.gov.in/aboutbbsr, last visited $08^{\text {th }}$ Aug 2016

[13]. http://www.odisha.gov.in/portal/ViewDetails.asp, last visited $08^{\text {th }}$ Aug 2016 